\title{
E-Marketing Sebagai Bentuk Pemasaran Darurat Dalam Meningkatkan Minat Pendaftar Pada Masa Pandemi Covid-19
}

\author{
Vivid Dekanawati ${ }^{*}$, Siti Fatimah ${ }^{2}$, Cahya Purnomo ${ }^{3}$, Sahudiyono ${ }^{4}$, Supartini ${ }^{5}$, \\ Aisyah Atinahsyani ${ }^{6}$ \\ 1,3,4,5,6 Sekolah Tinggi Maritim Yogyakarta, Jl. Magelang KM 4.4, Yogyakarta \\ 55284,Indonesia \\ ${ }^{2}$ Politeknik API Yogyakarta JL Wisata Babarsari TB XV/15 Yogyakarta, Tambak Bayan, \\ Caturtunggal, Kec. Depok, Kabupaten Sleman, Daerah Istimewa Yogyakarta 55281 \\ *Corresponding Author. E-mail: vividdek@gmail.com.HP: 0819-1088-9982
}

\begin{abstract}
Abstrak
Penelitian ini bertujuan untuk menemukan cara efektif bagaimana menarik perhatian pendaftar sebagai taruna baru di Sekolah Tinggi Maritim Yogyakarta dimasa pandemi Covid-19. Subyek penelitian ini adalah Taruna baru semester satu jurusan Diploma 3 Manajemen Transportasi Laut, Diploma 3 Permesinan Kapal, Diploma 3 Studi Nautika dan S1 Transportasi dikarenakan taruna tersebut masih sangat baru masuk menjadi taruna di Sekolah Tinggi Maritim Yogyakarta. Obyek Penelitian ini adalah E-Marketing, Pemasaran Darurat, Pemasaran di era Pandemi Covid-19 di Sekolah Tinggi Maritim Yogyakarta. Dari sisi perguruan tinggi sekolah maritim yang ada di Yogyakarta ini menunjukkan keunikannya dimana Yogyakarta belum mempunyai pelabuhan komersial untuk kapal-kapal cargo namun mampu mencetak lulusan di bidang kepelabuhanan dan kemaritiman. Metode pengumpulan data dalam penelitian ini menggunakan kuesioner. Analisis data menggunakan metode analisis regresi linier berganda. Hasil penelitian ini adalah variabel-variabel E-Marketing dan Pemasaran Darurat berpengaruh secara simultan terhadap pemasaran yang dilakukan di era Pandemi Covid-19, dimana interaksi tatap muka dibatasi. Pengaruh variabel independen yaitu e-marketing dan pemasaran darurat terhadap variabel dependen pemasaran yang dilakukan di era Pandemi Covid-19 adalah 70\%. Sedangkan 30\% dipengaruhi oleh variabel lain selain E-Marketing dan Pemasaran Darurat. Ini artinya eletronik marketing sangat efektif untuk menarik minat pendaftar.
\end{abstract}

Kata Kunci: E-Marketing, Pemasaran Darurat, Covid-19.

\begin{abstract}
This research was conducted to find an effective way to attract the attention of applicants as new cadets at the Sekolah Tinggi Maritim Yogyakarta during the Covid-19 pandemic. The subjects of this research are the first semester cadets majoring in Diploma 3 Marine Transportation Management, Diploma 3 Ship Engineering, Diploma 3 Nautical Studies and S1 Transportation because these cadets are still very new to become cadets at the Sekolah Tinggi Maritim Yogyakarta. The object of this research is E-Marketing, Emergency Marketing, Marketing in the era of the Covid-19 Pandemic at Sekolah Tinggi Maritim Yogyakarta. From the side of the Sekolah Tinggi Maritim Yogyakarta, it must show
\end{abstract}


its uniqueness to attract applicants without having to meet face to face like this maritime school in Yogyakarta where Yogyakarta does not yet have a commercial port for cargo ships. The results of this study are the variables of E-Marketing and Emergency Marketing have a simultaneous effect on marketing carried out in the Covid-19 Pandemic era. The effect of the independent variable E-Marketing and Emergency Marketing on the dependent variable is marketing carried out in the Covid-19 Pandemic era is $70 \%$. Meanwhile, 30\% is influenced by other variables besides E-Marketing and Emergency Marketing. Its mean that electronic marketing very effective to attract prospective applicants.

Keywords: E-Marketing, Emergency Marketing, Covid-19 Pandemic.

\section{PENDAHULUAN}

Akreditasi Institusi memberikan gambaran kualitas bagaimana sebuah sekolah/ perguruan tinggi sebagai alat pembinaan, pengembangan dan peningkatan perguruan tinggi baik dari segi mutu, efektivitas, efisiensi, produktivitas dan inovasinya berjalan. Akreditasi juga memberi keyakinan bahwa sekolah/perguruan tinggi telah melaksanakan kelayakan program pendidikan sesuai standar yang mengacu pada standar pendidikan nasional(Hakim, 2019).

Persaingan antar lembaga pendidikan semakin atraktif dan bervariasi. Pemasaran untuk lembaga pendidikan mutlak diperlukan. Menemukan cara yang tepat untuk meningkatkan kepuasan pelanggan (siswa/mahasiswa) harus menjadi strategi proses yang sangat mempengaruhi keberadaan penyedia jasa lembaga pendidikan karena, dalam hal ini Sekolah/Perguruan Tinggi) (Ramadhan \& Satibi, 2021). Oleh karena itu, diperlukan strategi pemasaran jasa pendidikan untuk memenangkan kompetisi antar sekolah serta untuk meningkatkan akselerasi peningkatan kualitas dan profesionalisme manajemen sekolah.

Jasa Pendidikan diberikan oleh suatu organisasi produksi yang menghasilkan jasa Pendidikan yang konsumen utamanya adalah siswa atau mahasiswa. Apabila produsen tidak mampu memasarkan hasil produksinya, disebabkan karena mutunya tidak disenangi oleh konsumen, tidak memberikan nilai tambah, layanan tidak memuaskan, maka produk jasa yang ditawarkan tidak akan laku, sehingga sekolah ditutup karena ketidakmampuan para pengelolanya. Dalam bisnis ini, bukan sekedar menyampaikan iklan dan promosi saja tapi meyakinkan masyarakat bahwa Lembaga Pendidikan yang dipilih adalah Lembaga yang bermutu dan mencetak lulusan yang bermanfaat di dunia kerja(Raya, 2016).

Banyak orang yang belum mengetahui tentang marketing di dunia Pendidikan. Terkadang mereka menganggap Pendidikan adalah jalan sedekah ilmu, mengabdi dan hanya menjalankan profesinya saja. Pada dasarnya Lembaga pendidikan termasuk ke dalam nonprofit organization, namun pada kenyataannya kegiatan melayani konsumen berupa siswa/mahasiswa merupakan kegiatan yang bisa dikomersilkan dan sangat menjanjikan karena upaya mencerdaskan bangsa tidaklah diberikan begitu saja(Arifin, 2020).

Lembaga pendidikan pada hakekatnya bertujuan memberikan layanan. Dalam pelayanan ini ada banyak kegiatan dari mulai bagaimana mendapatkan 
peminat, pengunjung untuk datang sekedar mendengar atau membaca apa yang ditawarkan sampai pada pelayanan ketika siswa/mahasiswa sudah menjadi bagian tetap dari Lembaga Pendidikan tersebut(Fradito, 2016). Jadi marketing jasa pendidikan berarti kegiatan lembaga pendidikan memberi layanan atau menyampaikan jasa pendidikan kepada konsumen dengan cara yang memuaskan. Pada tahun ajaran baru banyak bermunculan brosur, iklan-iklan, spanduk di pinggir jalan bahkan selebaran cetak tidak ketinggalan banyak menyasar konsumen di sekolah, tempat makan, tempat wisata dan lain sebagainya untuk menarik perhatian calon siswa bahkan mempengaruhi keluarga calon siswa. Mengapa sasaran keluarga calon siswa juga diperlukan dalam memasarkan produk Lembaga jasa Pendidikan? Ini dikarenakan pengaruh keluarga dari sisi ekonomi, bayangan anaknya akan menjadi apa di masa depan tergambar besar oleh keluarga calon siswa yang biasanya dilakukan oleh para orang tua yang lebih dulu mendapatkan refrensi tentang lembag jasa Pendidikan yang pernah dilaluinya.

Saat ini adalah kita dihadapkan pada masa pandemi Covid 19 yang pandemi ini melanda seluruh dunia. Perekonomian masyarakat sangat berpengaruh karena saat ini yang terpenting adalah bagaimana menyelamatkan diri dari serangan golongan Coronavirus yaitu SARS-CoV-2(Madura, 2020). Otomatis banyak minat melanjutkan sekolah ke tingkat perguruan tinggi menurun karena banyak perguruan tinggi yang sesuai dengan minat konsumen yang berbayar walaupun ada juga yang tidak namun harus menunjukkan berbagai syarat yang bisa saja tidak dapat dipenuhi oleh sebagian besar konsumen calon mahasiswa. Dengan posisi yang seperti ini membuat masing-masing perguruan tinggi berlomba-lomba untuk menarik lulusan SMA/SMK agar bisa melanjutkan pendidikan di tingkat Sarjana(Muhsin, 2021). Aspek keunikan masing-masing Perguruan Tinggi sampai pemberian diskon biaya harus ditonjolkan supaya lebih bisa menarik calon mahasiswa sehingga kelak menjadi bagian dari alumni almamater tertentu. Apalagi jika kita melihat banyak perguruan favorit yang dari puluhan tahun ke tahun tidak bergeser peminatnya. Keberadaan perguruan tinggi favorit ini semakin membuat perguruan tinggi lain menempatkan strategi dan harus menonjolkan keunikan dari lembaga jasa yang ditawarkannya. Pemasaran di era pandemi covid ada peluang besar namun juga ada ancaman yang menyertainya. Bagi pemasar, harus bisa menangkap peluang ini dan menjadikannya umpan untuk bisa menembus pasar global terbatas.

Menurut Kotler \& Armstrong (2010) e-marketing atau yang sering disebut adalah electronic marketing menggambarkan usaha yang dilakukan sebuah perusahaan mendeskripsikan setiap upaya yang dilakukan perusahaan untuk menjual informasi kepada pembeli, mengkomunikasikan, mempromosikan, dan menjual produk dan jasanya melalui media internet. Menurut Strauss \& Frost (2009) E-marketing adalah penggunaan teknologi informasi dalam secara online untuk mempromosikan dan memasarkan brang dan jasa untuk kepuasan pelanggan menjadi tujuannya. Didalamnya ada proses pembuatan, komunikasi dan memberikan nilai-nilai yang menguntungkan untuk kedua belah pihak atau relasi lain yang terlibat di dalamnya.

Pemasaran darurat adalah bentuk pemasaran yang karena beberapa strategi untuk bisa menarik konsumen sebanyak-banyaknya. Pemasaran darurat terjadi 
karena faktor keadaan lingkungan dan manusia yang membatasi pertemuan, pergerakan dan prilaku konsumen itu sendiri. Sudah 2 tahun ini, pandemi global menyebar hampir di seluruh negara dengan jumlah korban positif mencapai ratusan ribu orang bahkan lebih, termasuk Indonesia. Virus Corona di Indonesia terdeteksi pada awal Maret 2020 dan menyebar semakin masif setiap harinya. Dampak dari pandemi ini menyasar ke pendidikan, ekonomi, pariwisata dan berbagai bisnis dengan lapangan pekerjaan lainnya. Pandemi covid 19 membuat para pemasar mencari bagaimana cara yang paling efektif untuk memasarkan produknya. Efektivitas pemasaran adalah bagaimana perusahaan mencapai sasaran jangka pendek bahkan tujuan jangka panjang yang telah disepakati atau ditetapkan sebelumnya. Dapat juga diartikan apabila suatu pemasaran dalat dilakukan dengan baik dan tujuan perusahaan dapat tercapai, maka disebut pemasaran efektif. Kotler \& Armstrong (2010) Efektivitas Pemasaran adalah kualitas pemasar untuk mengoptimalkan upaya mereka dan mencapai hasil jangka pendek dan jangka panjang terbaik.

Corona virus merupakan suatu sekumpulan virus dari subfamili Orthocronaviriane dalam keluarga Coronaviridae dan ordo Nidovirales. Kelompok virrus ini dapat menyebabkan penyakit pada mamalia, burung dan bahkan menyerang manusia. Pada manusia, coronavirus dapat menyebabkan infeksi pada saluran pernapasan yang umumnya ringan seperti flu, meskipun beberapa bentuk penyakit seperti SARS, MERS, dan Covid-19 yang sifatnya lebih mematikan (Yunus \& Rezki, 2020). Keadaan yang di luar prediksi manusia ini memberikan perubahan besar di berbagai sektor, tidak terkecuali pendidikan. Pendidikan merasakan dampak signifikan akibat pandemi ini. Akibat perubahan dan pembaharuan kebijakan yang terjadi, peserta didik tidak lagi belajar di sekolah, tetapi cukup belajar di rumah dengan memakai sistem pembelajaran daring (online) jarak jauh menggunakan learning management system seperti edmodo, google classroom, moodle(Pertiwi et al., 2021). Sesuai Surat Edaran Mendikbud Nomor: 36962/MPK.A/HK/2020 pemerintah menghimbau agar pembejaran dilakukan secara daring/ stay at home( baca: belajar, bekerja, dan beribadah di rumah) dan menerapkan physical distancing (jaga jarak fisik antara satu dengan yang lain) untuk mencegah penyebaran Covid-19 (Astriawati \& Pratama, 2021).

Dampak Dari kebijakan pemerintah sebagai upaya untuk memutus rantai covid-19 perusahaan dan masyarakat sangat dirasa dampaknya. Perusahaan hanya bisa memprogram kegiatan dari gadget, sebagian tim produksi perusahaan/Instansi terpaksa dirumahkan sampai waktu yang tidak bisa dipastikan karena pandemi ini masih belum dipastikan kapan akan berakhir. Bagi masyarakat luas, pandemi ini sangat berdampak langsung pada pemenuhan kebutuhan karena pendapatan yang menurun. Menyikapi kondisi seperti ini perusahaan harus melakukan perombakan strategi pemasaran sebagai upaya untuk menjawab masalah konsumen dalam kesulitan mendapatkan produk yang dibutuhkan. Strategi yang dimaksud perusahaan merupakan strategi promosi melalui digital marketing. Digital marketing merupakan cara promosi dengan memanfaatkan kegunaan gadged seperti aplikasi - aplikasi, web-web yang bisa menghubungkan antara konsumen dan produsen (perusahaan). Menurut I Gede A dalam Lestari \& Saifuddin (2020) 
perusahaan bisa melakukan promosi melalui lima saluran dalam digital marketing yaitu: Website, Media Sosial, online advertising, forum discussion, Mobile aplication. Penelitian ini bertujuan untuk menemukan cara efektif bagaimana menarik perhatian pendaftar sebagai taruna baru di Sekolah Tinggi Maritim Yogyakarta dimasa pandemi Covid-19.

\section{METODE PENELITIAN}

Subyek penelitian ini adalah Taruna baru semester satu jurusan Diploma 3 Manajemen Transportasi Laut, Diploma 3 Permesinan Kapal, Diploma 3 Studi Nautika dan S1 Transportasi Laut dikarenakan taruna tersebut masih sangat baru masuk menjadi taruna di Sekolah Tinggi Maritim Yogyakarta. Obyek Penelitian ini adalah E-Marketing, Pemasaran Darurat, Pemasaran di era Pandemi Covid-19 di Sekolah Tinggi Maritim Yogyakarta. Populasi dalam penelitian ini adalah Taruna baru semester satu jurusan Diploma 3 Manajemen Transportasi Laut, Diploma 3 Permesinan Kapal, Diploma 3 Studi Nautika dan S1 Transportasi Laut di Sekolah Tinggi Maritim Yogyakarta. Sampel yang diambil dalam penelitian ini adalah Taruna baru semester satu jurusan Diploma 3 Manajemen Transportasi Laut, Diploma 3 Permesinan Kapal, Diploma 3 Studi Nautika dan S1 Transportasi Laut di Sekolah Tinggi Maritim Yogyakarta yang mau menjadi sampel penelitian. Sampel yang di ambil dengan menggunakan teknik pengambilan sampel secara convenience sampling. Convenience sampling dimana metode yang digunakan adalah mengumpulkan data dari responden untuk kemudahan bagi peneliti mendapatkan informasi yang berkaitan dengan penelitian. Dalam hal ini, sampling responden yang digunakan sejumlah 100 responden.

Dalam penelitian ini terdiri dari satu variabel dependen 2 variabel independen (bebas). Variabel -variabel tersebut adalah sebagai berikut : 1)Variabel independen (bebas): E-Marketing dan Pemasaran Darurat 2)Variabel dependen(terikat): Pemasaran di era Pandemi Covid-19. Karena jenis data yang di gunakan adalah primer, maka metode yang di gunakan adalah pengumpulan data secara langsung. Data-data yang didalam penelitian ini didapatkan dengan menyebarkan kuesioner yang berisi sejumlah pertanyaan kepada para responden.

Metode pengumpulan data dalam penelitian ini menggunakan kuesioner. Pengukuran variabel dilakukan dengan skala Likert yang menggunakan skoring.Peneliti menggunakan metode analisis regresi linier berganda dimana analisis tersebut tentang pengaruh variabel bebas (X) yang lebih dari satu terhadap variabel terikat (Y)(Astriawati, 2016). Alat uji instrumen menggunakan program SPSS release 17.0 for windows.

Uji kelayakan instrument dengan menggunakan uji validitas dan uji reliabilitas. Analisis ini digunakan untuk menguji valid tidaknya setiap pernyataan yang ada dalam kuesioner. Uji F statistika yaitu Pengujian secara seremtak (simultan) menggunakan uji F statistik untuk mengetahui apakah terdapat pengaruh atau tidak antara variabel bebas secara bersama-sama terhadap variabel terikatnya. Jika F hitung lebih besar dari $F$ tabel, maka terdapat pengaruh antara variabel bebas secara bersama-sama terhadap variabel terikat. 
Uji t statistik yaitu Uji ini di lakukan untuk mengetahui apakah ada pengaruh antara variabel bebas dengan variabel terikat secara parsial. jika terhitung lebih besar dari t-tabel, maka variabel bebasnya mempunyai pengaruh secara parsial terhadap variabel terikat, demikian pula sebaliknya. Menurut menurut Djawanto dalam Dekanawati \& Supartini (2019) koefisien determinasi untuk mengukur poporsi/presentasi sumbangan dari seluruh variabel bebas (X) yang lebih dari satu terhadap variabel terikat (Y).

\section{HASIL DAN PEMBAHASAN}

\section{Analisa Data}

\section{A. Uji kelayakan instrumen}

Analisis ini menggunakan uji kelayakan instrumen untuk menguji valid tidaknya setiap pernyataan yang ada dalam kuesioner. Pengujian dalam penelitian ini menggunakan derajat kepercayaan $5 \%$ dengan jumlah sampel $n=100$, maka di dapat nilai $\mathrm{df}=\mathrm{n}-2$, maka $\mathrm{df}=100-2=98$ diperoleh $\mathrm{R}$ tabel sebesar 0,165

\section{B. Uji Validitas}

1. Variabel E-Marketing (X1)

Tabel 1. Hasil Uji Validitas Variabel E-Marketing (X1)

\begin{tabular}{cccc}
\hline Butir & Nilai r (correlation) & Nilai Sig & Ket \\
\hline X1.1 & 0,669 & 0,000 & Valid \\
X1.2 & 0,412 & 0,000 & Valid \\
X1.3 & 0,418 & 0,000 & Valid \\
X1.4 & 0,469 & 0,000 & Valid \\
X1.5 & 0,494 & 0,000 & Valid \\
X1.6 & 0,761 & 0,000 & Valid \\
X1.7 & 0,381 & 0,000 & Valid \\
X1.8 & 0,504 & 0,000 & Valid \\
X1.9 & 0,761 & 0,000 & Valid \\
X1.10 & 0,450 & 0,000 & Valid \\
\hline
\end{tabular}

Tabel 1 diatas menunjukan bahwa semua butir pernyataan dari variabel emarketing dinyatakan valid karena semua butir mempunyai korelasi dengan taraf signifikansi $<0,05$ dan nilai $\mathrm{r}^{\text {hitung }}>0,165\left(\mathrm{r}^{\text {tabel }}\right)$.

2.Variabel Pemasaran Darurat

Tabel 2. Hasil Uji Validitas Variabel Pemasaran Darurat (X2)

\begin{tabular}{cccc}
\hline Butir & Nilai r (correlation) & Nilai Sig & Ket \\
\hline X2.1 & 0,455 & 0,000 & Valid \\
X2.2 & 0,839 & 0,000 & Valid \\
X2.3 & 0,839 & 0,000 & Valid \\
X2.4 & 0,532 & 0,000 & Valid \\
X2.5 & 0,257 & 0,000 & Valid \\
X2.6 & 0,839 & 0,000 & Valid \\
\hline \hline
\end{tabular}

Majalah Ilmiah Bahari Jogja 56 | http://jurnal.stimaryo.ac.id/index.php/MIBJ/ 
Tabel 2 diatas menunjukan bahwa semua butir pernyataan dari variabel Pemasaran Darurat dinyatakan valid karena semua butir mempunyai korelasi dengan taraf signifikansi $<0,05$ dan nilai $\mathrm{r}^{\text {hitung }}>0,165\left(\mathrm{r}^{\text {tabel }}\right)$.

3. Variabel Pemasaran di era Pandemi Covid-19

Tabel 3. Hasil Uji Validitas Variabel Pemasaran di era Pandemi Covid-19 (Y)

\begin{tabular}{cccc}
\hline Butir & Nilai r (correlation) & Nilai Sig & Ket \\
\hline Y.1 & 0,859 & 0,000 & Valid \\
Y.2 & 0,749 & 0,000 & Valid \\
Y.3 & 0,600 & 0,000 & Valid \\
Y.4 & 0,780 & 0,000 & Valid \\
Y.5 & 0,322 & 0,000 & Valid \\
Y.6 & 0,473 & 0,000 & Valid \\
Y.7 & 0,749 & 0,000 & Valid \\
Y.8 & 0,464 & 0,000 & Valid \\
Y.9 & 0,859 & 0,000 & Valid \\
Y.10 & 0,600 & 0,000 & Valid \\
Y.11 & 0,780 & 0,000 & Valid \\
Y.12 & 0,473 & 0,000 & Valid \\
\hline
\end{tabular}

Tabel 3 diatas menunjukan bahwa semua butir pernyataan dari variabel pemasaran di era pandemi Covid-19 dinyatakan valid karena semua butir mempunyai korelasi dengan taraf signifikansi $<0,05$ dan nilai $\mathrm{r}^{\text {hitung }}>0,165\left(\mathrm{r}^{\text {tabel }}\right)$.

\section{Uji Reliabilitas}

Uji reliabilitas digunakan untuk mengetahui suatu instrument cukup dapat di percaya untuk di gunakan sebagai alat pengumpul data,atau suatu angket dikatakan reliabel jika jawaban responden konsisten. Untuk menghitung reliabilitas masing-masing variabel dalam penelitian ini di gunakan Alpha Cronbach.

Tabel 4. Hasil Uji Reliabilitas

\begin{tabular}{ccc}
\hline Variabel & Alpha Cronbach & Ket \\
\hline E-Marketing & 0,716 & Reliabel \\
Pemasaran Darurat & 0,704 & Reliabel \\
Pemasaran di era Pandemi Covid-19 & 0,870 & Reliabel \\
\hline
\end{tabular}

Dari tabel diatas bahwa pada ketiga variabel yaitu E-Marketing (X1), Pemasaran Darurat (X2), Pemasaran di era Pandemi Covid-19 (Y) Alpha Cronbach menunjukkan nilai lebih dari 0,7 sehingga dikatakan bahwa instrumen yang digunakan di dalam penelitian memiliki reliabilitas yang baik.

\section{Analisis Regresi Linier Berganda}

Tabel 5. Hasil pengujian regresi linier berganda 
Coefficients $^{\mathrm{a}}$

\begin{tabular}{|c|c|c|c|c|c|c|c|c|c|}
\hline \multirow{2}{*}{\multicolumn{2}{|c|}{ Model }} & \multicolumn{2}{|c|}{$\begin{array}{l}\text { Unstandardized } \\
\text { Coefficients }\end{array}$} & \multirow{2}{*}{\begin{tabular}{|l} 
Standardized \\
Coefficients
\end{tabular}} & \multirow{2}{*}{$\mathrm{t}$} & \multirow{2}{*}{ Sig. } & \multicolumn{3}{|c|}{ Correlations } \\
\hline & & B & Std. Error & & & & $\begin{array}{l}\text { Zero- } \\
\text { order }\end{array}$ & Partial & Part \\
\hline \multirow[t]{3}{*}{1} & (Constant) & -5.059 & 3.425 & & -1.477 & .143 & & & \\
\hline & eMarketing & .945 & .096 & .633 & 9.863 & .000 & .795 & .708 & .543 \\
\hline & PemasaranEfektif & .656 & .133 & .316 & 4.928 & .000 & .641 & .447 & .271 \\
\hline
\end{tabular}

a. Dependent Variable: Pemasaran di era Pandemi Covid-19

Berdasarkan tabel 5 coefficients diatas maka dapat diperoleh persamaan regresi yaitu :

$$
\mathrm{Y}=-5.059+0.945 \mathrm{X} 1+0.656 \mathrm{X} 2
$$

Dari persamaan regresi linier berganda dalam tabel di atas dapat di ketahui bahwa:

1. Kontanta $\mathrm{a}=-5.059$ Artinya jika skor variabel e-marketing, pemasaran darurat konstan atau 0, maka skor pemasaran di era pandemi Covid-19 nilanya -5.059.

2. Nilai koefisien regresi e-marketing (b1) yang bertanda positif (0.945) menunjukkan adanya pengaruh yang positif antara e-marketing dengan pemasaran darurat di era Pandemi Covid-19. Artinya jika elektronik marketing yang diberikan tepat sasaran dan berkesan bagi calon Taruna Stimaryo, maka pemasaran yang di lakukan di era pandemi Covid-19 ini dapat meningkatkan jumlah peminat pendaftar.

3. Nilai koefisien regresi Pemasaran Darurat (b2) yang bertanda positif (0.656) menunjukkan adanya pengaruh yang positif antara pemasaran Darurat dengan pemasaran di era pandemi Covid-19. Artinya jika pemasaran yang dilakukan sudah efektif maka pemasaran yang dilakukan di era pandemi Covid-19 ini adalah jalan yang paling efektif untuk bisa menarik minat para pendaftar tanpa harus face to face atau bertatap muka lagi. Dengan kata lain pemasaran darurat merupakan hal terbaik yang dapat dilakukan saat ini untuk menghindari pertemuan antar penjual dan calon konsumen.

4. Dari hasil koefisien regeresi kedua variabel yang bernilai positif, berarti variabel independen tersebut mempunyai pengaruh positif terhadap variabel dependen.

\section{E. Uji F}

Tabel 6. Hasil nilai uji F

\begin{tabular}{|c|c|c|c|c|c|c|}
\hline \multicolumn{2}{|c|}{ Model } & Sum of Squares & $\mathrm{df}$ & Mean Square & $F$ & Sig. \\
\hline 1 & Regression & 2492.186 & 2 & 1246.093 & 116.383 & $.000^{\mathrm{a}}$ \\
\hline & Residual & 1038.564 & 97 & 10.707 & & \\
\hline & Total & 3530.750 & 99 & & & \\
\hline
\end{tabular}

a. Predictors: (Constant), Pemasaran Darurat, e Marketing

b. Dependent Variable: Pemasaran yang di lakukan di era Pandemi Covid-19

Dari hasil tabel 6 pengolahan data diatas diketahui bahwa nilai F-hitung adalah 116.383 dengan nilai signifikan sebesar 0,000, dan nilai F-tabel adalah 3,090 
dengan demikian dapat di simpulkan bahwa F-hitung $>$ F-tabel dengan tingkat signifikan $0,000<0,05(\mathrm{p}<0,05)$, maka Ho ditolak dan Ha diterima berarti variabelvariabel e-marketing dan pemasaran darurat berpengaruh secara simultan terhadap pemasaran yang dilakukan di era pandemi Covid-19.

\section{F. Uji T}

Tabel 7. Hasil nilai uji t

\begin{tabular}{ccccc}
\hline Variabel & T hitung & T tabel & Sig & Ket \\
\hline E-Marketing & 9.863 & 1,661 & 0,000 & Signifikan \\
Pemasaran Darurat & 4.928 & 1,661 & 0,000 & Signifikan \\
\hline
\end{tabular}

Dari hasil olah data di atas diketahui t-hitung masing-masing variabel adalah:Variabel E-Marketing t-hitung lebih besar dari t-tabel $(9.863>1,661)$ dengan porbalitas $(0,000)$ lebih kecil dari taraf signifikan 0,05 dengan demikinan Ho di tolak dan Ha diterima,artinya variabel e-marketing mempunyai pengaruh yang signifikan terhadap pemasaran yang dilakukan di era pandemi Covid-19 dan variabel pemasaran darurat t-hitung lebih besar dari t-tabel $(4.928>1,661)$ dengan porbalitas $(0,000)$ lebih besar dari taraf signifikan 0,05 dengan demikinan Ho di terima dan Ha ditolak, artinya variabel pemasaran darurat mempunyai pengaruh yang signifikan terhadap pemasaran yang dilakukan di era Pandemi Covid-19.

\section{G.Koefisien determinasi}

Tabel 8. Hasil analisis uji koefisien determinasi

Model Summary

\begin{tabular}{|l|l|l|l|l|}
\hline Model & R & R Square & Adjusted R Square & Std. Error of the Estimate \\
\hline 1 & $.840^{\mathrm{a}}$ & .706 & .700 & 3.272 \\
\hline
\end{tabular}

a. Predictors: (Constant), PemasaranEfektif, eMarketing

b. Dependent Variable: Pemasaran yang di lakukan di era Pandemi Covid-19

Dari perhitungan diatas diperoleh nilai besarnya koefisien determinasi adalah 0.700 hal ini menunjukkan bahwa pengaruh variabel independen (E-Marketing dan Pemasaran Darurat) terhadap variabel dependen (Pemasaran yang di lakukan di era Pandemi Covid-19) adalah 70\%. Sedangkan 30\% dipengaruhi oleh variabel lain selain E-Marketing dan Pemasaran Darurat.

\section{SIMPULAN}

Berdasarkan hasil coefficients maka dapat diperoleh persamaan regresi yaitu $: \mathrm{Y}=-5.059+0.945 \mathrm{X} 1+0.656 \mathrm{X} 2$. Nilai F-hitung adalah 116.383 dengan nilai signifikan sebesar 0,000, dan nilai F-tabel adalah 3,090, berarti variabel-variabel e-Marketing dan pemasaran Darurat berpengaruh secara simultan terhadap pemasaran yang dilakukan di era Pandemi Covid-19. Variabel E-Marketing thitung lebih besar dari t-tabel $(9.863>1,661)$, artinya variabel E-Marketing mempunyai pengaruh yang signifikan terhadap pemasaran yang di lakukan di era pandemi Covid-19 dan variabel pemasaran darurat t-hitung lebih besar dari t-tabel (4.928 $>1,661)$, artinya variabel pemasaran darurat mempunyai pengaruh yang signifikan terhadap pemasaran yang dilakukan di era pandemi Covid-19.Nilai 
koefisien determinasi adalah 0.700 hal ini menunjukkan bahwa pengaruh variabel independen (E-Marketing dan Pemasaran Darurat) terhadap variabel dependen (pemasaran yang di lakukan di era pandemi Covid-19) adalah 70\%. Sedangkan 30\% dipengaruhi oleh variabel lain selain e-marketing dan pemasaran darurat. Ini artinya elektronik marketing sangat efektif untuk menarik minat pendaftar.

\section{DAFTAR PUSTAKA}

Arifin, S. (2020). Marketing Pendidikan. Tadris: Jurnal Penelitian Dan Pemikiran Pendidikan Islam, 14(1), 112-123.

Astriawati, N. (2016). Penerapan Analisis Regresi Linier Berganda Untuk Menentukan Pengaruh Pelayanan Pendidikan Terhadap Efektifitas Belajar Taruna Di Akademi Maritim Yogyakarta. Majalah Ilmiah Bahari Jogja, 14(23), 22-37.

Astriawati, N., \& Pratama, H. A. (2021). Cadets' Effectivity and Perception on Moodle Online Learning in Economy Mathematics Course. Proceedings of the 1st International Conference on Mathematics and Mathematics Education (ICMMEd 2020), 550, 34-39. https://doi.org/10.2991/ASSEHR.K.210508.039

Dekanawati, V., \& Supartini, S. (2019). Pengaruh Kualitas Fungsional Dan Kualitas Teknikal Terhadap Kepuasaan Mahasiswa Peserta Pelatihan Kepabeanan Tahun 2018. Majalah Ilmiah Bahari Jogja, 17(2), 53-62.

Fradito, A. (2016). Strategi pemasaran pendidikan dalam meningkatkan citra Lembaga Pendidikan Islam: Studi Multikasus di SDI Surya Buana dan MIN Malang 2. Universitas Islam Negeri Maulana Malik Ibrahim.

Hakim, A. L. (2019). Pengembangan Matriks antar Standar Nasional Pendidikan Tinggi, Akreditasi Perguruan Tinggi dan Akreditasi Program Studi. Jurnal Ilmiah Kesehatan, 18(2), 42-48.

Kotler, P., \& Armstrong, G. (2010). Principles of marketing. Pearson education.

Lestari, P., \& Saifuddin, M. (2020). Implementasi strategi promosi produk dalam proses keputusan pembelian melalui digital marketing saat pandemi covid'19. Jurnal Manajemen Dan Inovasi (MANOVA), 3(2), 23-31.

Madura, D. F. T. I. (2020). DILEMA PERGURUAN TINGGI DALAM MENERAPKAN PEMBELAJARAN DARING DI MASA PANDEMI COVID-19. Bunga Rampai, 65.

Muhsin, H. (2021). Kampus Merdeka Di Era New Normal. Masa Depan Kampus Merdeka \& Merdeka Belajar: Sebuah Bunga Rampai Dosen, 143.

Pertiwi, Y., Astriawati, N., Wibowo, W., \& Kristianto, L. (2021). Moodle Virtual Class Effectivity toward Cadets’ Learning Motivation and Speaking Ability. Ethical Lingua: Journal of Language Teaching and Literature, 8(2), 378-383.

Ramadhan, M., \& Satibi, H. I. (2021). STRATEGI MARKETING PENDIDIKAN DI MADRASAH (Studi Analisis di MI Plus Jaryul Ulum Kalipurwo Kuwarasan). Institut Agama Islam Nahdlatul Ulama (IAINU) Kebumen.

Raya, M. K. F. (2016). Marketing Jasa Di Institusi Pendidikan (Analisis Pemasaran Dalam Pendidikan). FALASIFA: Jurnal Studi Keislaman, 7(1), 21-52. 
Strauss, J., \& Frost, R. (2009). E-Marketing, 35, 70, 234. New Jersey: Pearson Education.

Yunus, N. R., \& Rezki, A. (2020). Kebijakan pemberlakuan lock down sebagai antisipasi penyebaran corona virus Covid-19. Salam: Jurnal Sosial Dan Budaya Syar-I, 7(3), 227-238. 